\title{
SANTIAGO - VILLARRICA - BARCELONA: THE STATISTICAL INVESTIGATIVE CYCLE IN PRIMARY EDUCATION TEACHER TRAINING
}

\author{
FRANCISCA M. UBILLA \\ Universitat Autònoma de Barcelona \\ francisca.manriquez@e-campus.uab.cat \\ CLAUDIA VÁSQUEZ \\ Pontificia Universidad Católica de Chile \\ cavasque@uc.cl \\ FRANCISCO ROJAS \\ Pontificia Universidad Católica de Chile \\ frojass@uc.cl \\ NÚRIA GORGORIÓ \\ Universitat Autònoma de Barcelona \\ nuria.gorgorio@uab.cat
}

\begin{abstract}
We consider the ability to complete an investigative cycle as an indicator of the robustness of students' statistical knowledge. From this standpoint, we analyzed the written reports of primary education student teachers when they developed an investigative cycle in a Chilean and a Spanish university. In their development of the stages of the cycle we observed characteristics common to the centers (for example, summary research questions and conclusions that are a simple concatenation of results), and differential features (the data collection tools and techniques, among others). Armed with knowledge of how future teachers approach and understand an investigative cycle, we are able to contribute ideas that influence their training, building bridges between what they learn and what they should teach.
\end{abstract}

Keywords: Statistics education research; Primary teacher training; Statistical investigative cycle

\section{INTRODUCTION}

Statistical education is crucial if citizens are to effectively face the challenges of society (Batanero \& Borovcnik, 2016; Ben-Zvi et al., 2018). It provides tools to understand and respond to real problems and problems of other disciplines (Begg, 1997), and it enables connections to be made between different contexts and problems (Arteaga, 2011). It is vital that citizens have sufficient statistical knowledge to understand, interpret, critically evaluate and express opinions, and make informed decisions (Gal, 2002).

Statistics education is the work of teachers in compulsory education. Unfortunately, they are often not sufficiently well trained (Vásquez \& Alsina, 2017, 2019) to go beyond the teaching of technical knowledge to solve decontextualized problems. Thus, the statistics class becomes an arithmetic class, where no more than formulas are applied mechanically and meaninglessly (Batanero \& Díaz, 2011). Given this situation, like Batanero and Borovcnik (2016), we consider it necessary to provide teachers with the disciplinary and didactic tools needed to teach statistics, understanding it as a resource to solve problems. This explains our interest in the foundational training of new generations of teachers.

Our research focuses on the initial training of basic education student teachers at the Pontifical Catholic University of Chile (PUC) - with students from the San Joaquin campus in Santiago de Chile (from now on SCL) and the Villarrica campus (from now on VLR) - and primary education student teachers at the Autonomous University of Barcelona (UAB). In Chile, the term "basic education" refers 
to the first part of compulsory education, from 6 to 12 years old, which corresponds to primary education in Spain. From here on, we will use the generic term, teachers, to refer to teachers of this stage.

The PUC is a state-sponsored private institution and one of the leading universities in Chile. It has been training teachers since 1952 at SCL and since 1937 at VLR. The current training program has been in force since 2012 at both centers. On a national level, the candidates for teacher training with the highest grades enter the PUC. Although the SCL and VLR campuses follow the same curriculum, they both differ in the size of the program-SCL admits between 150 and 170 students annually, VLR between 30 and 50 - and in the social, cultural and economic characteristics of their areas of influence. The UAB is a Spanish public university and has offered teacher training since 1973. The current program has been in force since 2009 and around 250 new students are admitted every year. The UAB education programs are among the most highly reputed in Spain. The grade cut-off for access to the UAB Primary Education Degree is the highest among the Catalan universities offering this type of studies.

Chile and Spain share some of their history and have comparable core curricula and training institutions for teachers. In the two cases, statistics has its own syllabus, both in compulsory education and teacher training. In both countries, those currently studying to become teachers followed core curricula during their compulsory education that are different to those that will mark their activity as teachers. The conception of what statistics teaching should involve has also changed. Therefore, we thought it interesting to explore to what extent the training we offer prepares teachers to teach statistics. The final goal of our research was to generate knowledge that helps to improve the training we offer, building bridges between what they learned and what they should teach. Thanks to this research, developed in two countries at three centers with different characteristics, we were able to identify aspects that may not have been apparent in a single context.

\section{THE PROBLEM IN CONTEXT}

Given that our interest is focused on how, through training programs, we can help future teachers learn to teach statistics differently from the way they learned it themselves, we were interested in identifying the "statistical trajectory" of the participants in this study. Thus, in the first section we summarize the goals and content of the curriculum in force during the participants compulsory education and describe the possible academic paths followed before enrolling in the programs and also the statistical training currently offered by the programs. In the second section, we justify the choice of the statistical investigative cycle as a reference in our research and, in the third, we define the research problem and research purposes.

\subsection{STATISTICS AND TEACHER TRAINING AT SCL, VLR AND UAB}

Statistics in compulsory education. For this study, we focused on secondary education in Chile and compulsory secondary education in Catalonia because these stages encapsulate students' previous statistical learning, the goals and content with which they enroll in teacher training programs.

Table 1 shows the minimum statistical content in secondary education in Chile and in compulsory secondary education in Catalonia, at the time the participants in this study completed these stages. In Chile, this was established by the Ministry of Education Statutory Order No. 254, passed in 2009, which regulates the fundamental goals and minimum compulsory content of secondary education and lays down general standards for their application; and in Catalonia, by Statutory Order 143/2007, which regulated the teaching of compulsory secondary education. 
Table 1. Statistics in secondary education in Chile (Statutory Order No. 254/2009) and compulsory secondary education in Catalonia (Statutory Order 143/2007)

\begin{tabular}{lc}
\hline & \multicolumn{1}{c}{ Goals and curricula } \\
\hline Chile & $\begin{array}{c}\text { Goals: to develop concepts and techniques of statistics and probability theory that enable } \\
\text { students to critically evaluate statistical information and make inferences from }\end{array}$ \\
Secondary & information of a statistical nature. \\
Education & Curriculum content: graphs: bar, pie, line chart, boxplot, steam and leaf, histogram, \\
(14-18 years old) & $\begin{array}{c}\text { frequency polygon; centralization, dispersion and position measures; data } \\
\text { organization and representation; data intervals; discrete and continuous random }\end{array}$ \\
& variable; density function and probability distribution; expected value, variance and \\
& standard deviation; normal distribution, confidence intervals, binomial model. \\
Catalonia & Goals: to formulate questions that can be tackled with relevant data; collecting, organizing \\
Compulsory & and presenting relevant data to answer them; selecting and using appropriate statistical \\
Secondary & methods to analyze data, developing and evaluating inferences and predictions based \\
(12-16 years old) & on data; its application to other scientific fields and contexts; using spreadsheets and \\
& ICTs. \\
& Curriculum content: statistical study design; samples; randomness in experiments; discrete \\
and continuous variables; data tables; absolute and relative frequency; graphs: bar, pie, \\
line chart, boxplot, histogram, and point clouds; intervals, histograms and frequency \\
polygons; point clouds and regression line; centralization, dispersion and position \\
measures.
\end{tabular}

Mathematics and access to teacher-training programs. In Chile, the participants in this study had all completed compulsory education (basic from 6 to 14, and secondary from 14 to 18), a stage in which they were taught a minimum of 1,938 hours of mathematics. In the last two years of their secondary education, they took one of the three available tracks Humanist-Scientific (HS), Technical-Professional, or Artistic. All participants had completed the mathematics syllabus of the core curriculum. Those who chose the humanist-scientific track may have also studied optional, more advanced mathematics courses.

To enroll for teacher training, they had to take the university selection examinations (Prueba de Selección Universitaria [PSU]), which include a mathematics test corresponding to the compulsory secondary education curriculum. In the case of SCL, the students had all obtained grades equal to or higher than 600 points, well above the minimum established by the legislation that regulates the professional training of teachers. All programs in Chile establish a weighted average to calculate their admission mark. The weighted average of the compulsory PSU tests is $20 \%$ at both centers, although VLR gives greater weight to the ranking of middle school grades than SCL.

In Spain, compulsory education ends at 16 years of age and post-compulsory secondary school education does not necessarily include mathematics courses. Thus, all the participants from the UAB in this study had completed compulsory education (primary from 6 to 12, secondary from 12 to 16) with a minimum total of 1,050 hours of mathematics. They enrolled in the program in various ways, either by completing one of the different branches of the Bachillerato (the two years of non-compulsory, pre-university secondary education, hereinafter referred to as the baccalaureate) or through a vocational training cycle. Only those who had specialized in science and technology or social sciences had studied mathematics after compulsory education. All the baccalaureate students enrolled on the degree program had to pass the university entrance examinations (Pruebas de Acceso a la Universidad [PAU]). In these examinations, only those who studied mathematics during their baccalaureate had to take the mathematics section. The students from vocational training programs may have been allowed to enroll for teacher training without having taken the university entrance examinations. Therefore, not all the participants from the UAB had studied mathematics beyond the age of 16. Nonetheless, they had to pass a personal aptitude test (Prova d'Aptitud Personal [PAP]), compulsory in Catalonia since 2017, which includes a section on basic mathematics. 
Statistics on the teacher-training programs at SCL, VLR and the UAB. At the PUC, both on the SCL and VLR campuses, the common curriculum for all specialties (first four years) includes three courses in mathematics and two in didactics of mathematics. Students specialize in the fifth year, mathematics being one of the four possible choices. The complete program consists of $500 \mathrm{UC}$ creditsone UC credit corresponds to one hour of student work, either in-class or autonomous. Out of this total, in the common part 30 credits correspond to mathematics and 20 to its didactics. A third of the mathematics content block, ten UCs, corresponds to data analysis. This subject is taught in the fourth semester, with a total of five hours and twenty minutes class contact time at SCL and two hours and forty minutes at VLR. It provides a basic knowledge of statistics and probability, affording a solid foundation in the concepts to be taught and the basic statistical tools needed for professional teaching.

At the UAB, the primary education teacher-training program has 240 ECTS (European Credit Transfer System) credits. An ECTS credit amounts to around 25 hours of student academic work, either in-class, supervised or autonomous. In the common curriculum, seventeen ECTS credits correspond to mathematics and its teaching. The subject Mathematics for Teachers, with exclusively mathematical content, is allocated a total of six ECTS credits and is taught in the second semester, with a total of 40 hours of class contact time and five blocks, one of them statistical. This reviews the curricular content of primary education and the first two years of compulsory secondary education, working around the idea of an investigative cycle.

Taking as a whole what has been described in this section, the objectives and statistics content in the compulsory stage are observed to be practically the same in Chile and in Spain. However, the minimum number of hours of mathematics completed during compulsory education by students on the SCL and VLR programs is significantly greater than the hours completed during compulsory education by students on the UAB program. In contrast, the number of hours dedicated to mathematics and its didactics on the UAB program is much greater than on the SCL and VLR programs.

\subsection{THE INVESTIGATIVE CYCLE}

The teaching of statistics moves in a continuum between two extremes. For one of them, the emphasis is on understanding concepts and mastering representations and procedures, giving little importance to the context. At the other extreme, the importance lies in problem solving, and concepts are learned in context through statistical research. From our standpoint "statistics are inseparable from their applications and their final justification is their usefulness in solving problems external to the statistics themselves" (Batanero \& Díaz, 2011, p. 21). By choosing a topic of interest, defining objectives, selecting tools to collect data and analyze it, student teachers learn to appreciate the usefulness of statistics and consolidate the knowledge they will need to teach it.

When reviewing the theoretical frameworks that described statistical practice, we found that Watson et al. (2018) included some of particular interest. Specifically, Holmes (1980) suggested organizing the curriculum into five sections: data collection, data tabulation and representation, data reduction, probability, and interpretation and inference. Bright and Friel (1998) proposed a statistical investigation with four stages: posing the question, collecting the data, analyzing the data and interpreting the results. For their part, Wild and Pfannkuch (1999) established that the cyclic process of statistical investigation consists of five stages, which we review below. Franklin et al. (2007) proposed four steps in statistics teaching and variation should be made explicit in each one: formulating the question, collecting data, analyzing data and interpreting results. From the perspective of Spanish speakers, Batanero and Díaz (2011), in the framework of project work in compulsory education, proposed posing a problem, generating questions, collecting data, organizing, analyzing and interpreting the data, and then confirming that the problem has been solved.

Wild and Pfannkuch (1999) established four dimensions to characterize statistical thinking: the investigative cycle, the types of thinking, the interrogative cycle and the dispositions. Dimension 1 corresponds to the investigative cycle (from now on IC) represented in Figure 1, which comprises five stages: problem, plan, data, analysis, and conclusions. 


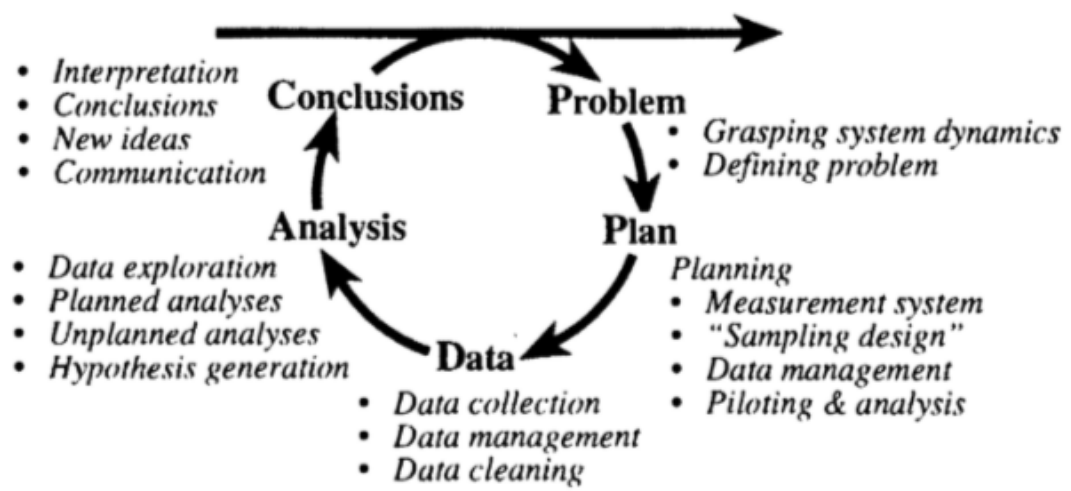

Figure 1. The investigative cycle (Wild \& Pfannkuch, 1999, p. 226)

A cycle of statistical investigation begins with the formulation of a research question. Arnold (2013) and Arnold and Pfannkuch (2019) stressed the importance of question posing, not only at the beginning of the IC, by way of research questions, but also to design the questions to be included in the data collection tool. Research questions must be of a statistical nature (Makar \& Fielding-Wells, 2011) and can be of different types - classified as summary, comparison or relationship questions (Pfannkuch \& Horring, 2005). It is necessary to know how to differentiate between questions that demand a deterministic resolution and others that need to be answered through a set of data (Franklin et al., 2007).

In the planning stage, the relationship between population and sample must be understood. Pfannkuch et al. (2015) think that due consideration must be given to the choice and size of the sample in order to make inferences about the population, while not forgetting the inevitable variation in the sampling process. In the data analysis stage, Wild and Pfannkuch (1999) highlighted transnumeration as a fundamental form of statistical thinking, which consists of modifying the data format to obtain further information. Although transnumeration can be supported by technological resources, it is important that students are able to assess the relevance of using different graphs or statistical measures (Garfield, 2002). In the final IC stage, the original question must be answered, generating knowledge in the context of the research, and applying the concepts and procedures of descriptive and inferential statistics (Makar \& Rubin, 2018). Given the above, Ubilla et al. (2019) proposed a system of categories that served to characterize the ICs developed by student teachers.

Burgess (2008) highlighted the importance of teachers having the knowledge and didactic tools necessary to guide their students in the development of statistical investigations. As in Makar and Fielding-Wells (2011), we consider that if students are to develop investigative skills, their teachers must introduce them to statistical research and support them throughout the IC. For this purpose, we took the IC of Wild and Pfannkuch (1999) as a reference, since it reflected our vision of statistics teaching while also including those procedures for solving statistical problems in context that teachers must master in order to teach them. Thus, it is worth ensuring that future teachers can successfully complete ICs.

Moreover, our review of curricular content showed that, both in Chile and in Catalonia, the goals and content of compulsory secondary education fall into line with the idea of the IC proposed by Wild and Pfannkuch (1999). In addition, the development of an IC is part of the UAB syllabus and can be incorporated into the teaching at the PUC without distorting the aims of the subject matter. All things considered, we decided to use the IC as data collection tool for our research, and the categories proposed in Ubilla et al. (2019) as references for data analysis.

\subsection{POSING THE PROBLEM AND IDENTIFYING GOALS}

Given the above, where the ability to complete an IC (Wild \& Pfannkuch, 1999) is considered an indicator of the robustness of the statistical knowledge of future teachers, this study sought to identify common characteristics and differential aspects in the written reports of student teachers at the three centers - SCL, VLR and UAB - when they develop an IC. 
Specifically, we set two research goals:

a) to characterize the different components that appear in the student teachers' reports during each of the IC stages.

b) to characterize the similarities and differences in the way the reports of the student teachers at the three centers specify the different stages.

Knowing how future teachers understand and tackle ICs can generate knowledge that may improve the training offered by the programs and thereby help them to link what they learned and how they learned it with the knowledge and teaching strategies they will need in their future teaching practice. Working at three different centers with common references was a way of identifying issues that might go unnoticed in national studies, offering the opportunity to go beyond what is known about each center.

\section{METHOD}

\subsection{DATA COLLECTION TOOL}

From the standpoint of an interpretive paradigm with a qualitative focus (Cohen et al., 2000), we presented the participants with an activity that guides them in the development of an IC. The activity had six steps, the first five related to the IC and the sixth oriented to reflect on the activity itself. The data collection tool that we gave the students consisted of the activity shown in Figure 2.

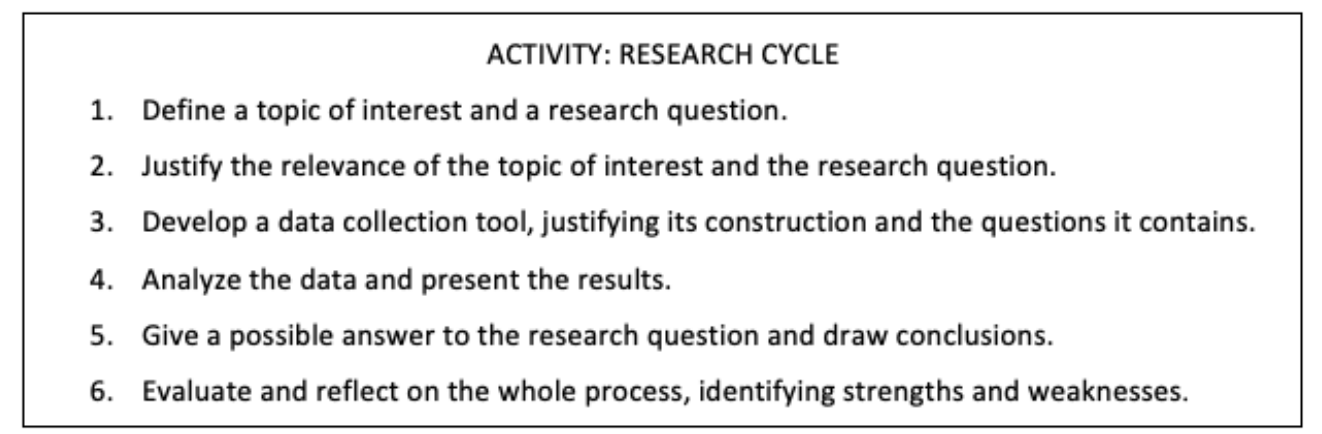

Figure 2. Activity presented to the future teachers

\subsection{PARTICIPANTS AND DATA COLLECTION}

The PUC students, on the SCL and VLR campuses, were pursuing a teaching degree in basic general education, and the students at the UAB a primary education teaching degree. Table 2 shows the participants' characteristics and the data collection process, presenting, for each center, the subject into which data collection was inserted, the semester when it was taught, the total number of participants, their previous education, and the number of working groups that were set up. We note that the only antecedents in statistics training shared by all three sets of students corresponded to the compulsory education stage. It should be pointed out that in contrast with the students at the UAB, the SCL and VLR students had completed a data analysis course during the fourth semester of their studies. 
Table 2: Participants and data collection

\begin{tabular}{|c|c|c|c|c|c|c|c|}
\hline Campus & Subject matter & Semester & $\begin{array}{c}\text { Total } \\
\text { students }\end{array}$ & \multicolumn{3}{|c|}{ Previous studies (\%) } & $\begin{array}{l}\begin{array}{l}\text { Working } \\
\text { groups }\end{array} \\
\end{array}$ \\
\hline \multirow[t]{2}{*}{ SCL } & Mathematics & $6^{\circ}$ & 20 & \multirow{2}{*}{\multicolumn{2}{|c|}{$\begin{array}{l}\text { Humanistic-Scientific } \\
\text { Technical-Professional }\end{array}$}} & 95 & 6 \\
\hline & Didactics II & & & & & 5 & \\
\hline \multirow[t]{8}{*}{ VLR } & Mathematics & $5^{\circ}$ & 15 & \multicolumn{2}{|c|}{ Technical-Professional } & 40 & 5 \\
\hline & Didactics I & & & \multicolumn{2}{|c|}{$\begin{array}{l}\text { Humanistic-Scientific } \\
\text { Technical-Professional }\end{array}$} & 20 & \\
\hline & & & & \multicolumn{2}{|l|}{ Open } & 13 & \\
\hline & & & & \multicolumn{2}{|l|}{ Unknown } & 27 & \\
\hline & Mathematics & $6^{\circ}$ & 31 & \multicolumn{2}{|c|}{ Humanistic-Scientific } & 55 & 10 \\
\hline & Didactics II & & & \multicolumn{2}{|c|}{ Technical-Professional } & 19 & \\
\hline & & & & \multicolumn{2}{|l|}{ Open } & 3 & \\
\hline & & & & \multirow{7}{*}{ Baccalaureate } & & 23 & \\
\hline \multirow{8}{*}{$\mathrm{UAB}$} & Mathematics & $2^{\circ}$ & 134 & & Humanities- & 54 & 34 \\
\hline & for Teachers & & & & Social & & \\
\hline & & & & & $\begin{array}{l}\text { Sciences } \\
\text { Science- }\end{array}$ & & \\
\hline & & & & & $\begin{array}{l}\text { Sclence- } \\
\text { Technology }\end{array}$ & 11 & \\
\hline & & & & & Arts & 3 & \\
\hline & & & & & Unknown & 6 & \\
\hline & & & & \multirow{2}{*}{\multicolumn{2}{|c|}{$\begin{array}{l}\text { Training cycle } \\
\text { Others }\end{array}$}} & 23 & \\
\hline & & & & & & 3 & \\
\hline
\end{tabular}

The activity took place in four sessions, 80 minutes each at the SCL and VLR centers and 90 minutes at the UAB. In the first session at SCL and VLR, the components making up an IC were explained to the students, indicating their presence in the current Chilean basic education curriculum. At the UAB, the first session reviewed the statistical concepts of compulsory education. At the three centers, the rest of the sessions were dedicated to the development of the activity.

Our data comes from the written reports of the 55 working groups, which were handed in after completing the activity in Figure 2. Each group was made up of three or four students who came together freely, according to their preferences. These data were complemented by the observations collected by the first author. At all three centers, most of the groups were made up of women only, which was reflective of their majority presence in teacher training programs (90\% women at SCL, 70\% at VLR, and $82 \%$ at the UAB).

\section{ANALYSIS}

We used a combined deductive and inductive approach to carry out a content analysis of the students' written reports. In each phase, we identified units of meaning in the written reports of the groups and organized them according to the categories designed by Ubilla et al. (2019). When differences in the data from the different centers emerged in some of the established categories, we carried out an inductive analysis, generating new categories to classify these different units of meaning.

Next, we summarize the analysis, structuring its presentation around the IC stages. For each stage and its components, we present the categories and subcategories of analysis (in italics), defining them when their meaning is not obvious and accompanying them with examples to illustrate how units of meaning were assigned to categories. When the categories do not correspond exactly with those established by Ubilla et al. (2019), this is specified. At the beginning of the section corresponding to the analysis of each stage, we present the categories from which we started the process of deductive analysis. When, on analyzing our data, we needed to generate new categories through an inductive process, we explain why we created them and how they arose. However, we only include them in the results section corresponding to the said phase. We exemplify the process of analysis on the basis of units of meaning drawn from the written productions of the groups, coding them with the letter $G$ followed by the group number and the initials of the center. Thus, G3UAB corresponds to Group 3 at the UAB. 
Stage 1: Problem. The categories used for the analysis of this stage are shown in Table 3. The first column in the table shows the components defined by Wild and Pfannkuch (1999) to describe the problem phase of the IC. The second and third columns show the categories proposed by Ubilla et al. (2019) to describe each of these components. In the research purpose and/or question category, the nature subcategory refers to the nature of the research question, as proposed by Makar and FieldingWells (2011), while the types of research questions correspond to those defined by Arnold (2013).

Table 3. Categories for Stage 1-Problem

\begin{tabular}{|c|c|c|c|}
\hline Components & \multicolumn{3}{|l|}{ Categories } \\
\hline $\begin{array}{l}\text { Capturing the } \\
\text { dynamics of the } \\
\text { context }\end{array}$ & $\begin{array}{l}\text { Rationale - justification of a } \\
\text { research topic based on: }\end{array}$ & \multicolumn{2}{|c|}{$\begin{array}{l}\text { its relevance in their context } \\
\text { their curiosity about an observation } \\
\text { an interest whose source is unspecified }\end{array}$} \\
\hline Problem definition & Research focus & \multicolumn{2}{|l|}{ explicit or not } \\
\hline & $\begin{array}{l}\text { Research purpose and/or } \\
\text { question }\end{array}$ & type & $\begin{array}{l}\text { statistical } \\
\text { non-statistical } \\
\text { summary } \\
\text { comparison } \\
\text { relationship }\end{array}$ \\
\hline
\end{tabular}

Below, we exemplify the assignment of units of meaning to the rationale category, including the group they come from, the text and the designated subcategory.

G17SCL: This topic is considered relevant because it is something that affects relevance everyone and can significantly influence the experience of university as regards the motivation needed to attend classes and $[\ldots]$

G2VLR: We are very concerned about the number of smokers at the university, in particular on our campus.

G30UAB: We have chosen this topic because the group members find it unspecified interest interesting and motivating.

We found differences in the context in which the research focus is established. We used an inductive process to create a new category, setting, with two new subcategories. Thus, we identified some research focuses related to the students' university studies and others linked to leisure topics. We incorporated these new subcategories into the results.

Below, we present examples from the type categories linked to the research purpose or question:

G7SCL: How do we dedicate time to leisure and for how long?

summary

G35UAB: Observe if there are differences in the field of sport as regards comparison gender

G5VLR: Does musical taste influence your study method?

relationship

Furthermore, our analysis differentiated between the research purpose and research question as enunciated by the participants. We include this differentiation when presenting the results.

Stage 2: Plan. Table 4 shows the categories used for the analysis of the second stage-plan. The table shows the components defined by Wild and Pfannkuch (1999) to describe this phase of the IC. The categories were specially constructed for the analysis developed by Ubilla et al. (2019). 
Table 4. Categories for Stage 2 - Plan

\begin{tabular}{|c|c|c|c|}
\hline Components & \multicolumn{3}{|l|}{ Categories } \\
\hline $\begin{array}{l}\text { Hypothesis } \\
\text { formulation }\end{array}$ & \multicolumn{3}{|c|}{ Hypothesis to be tested made explicit } \\
\hline \multirow[t]{4}{*}{$\begin{array}{l}\text { Data } \\
\text { collection } \\
\text { instrument }\end{array}$} & $\begin{array}{l}\text { Format of the } \\
\text { questions }\end{array}$ & $\begin{array}{l}\text { all closed } \\
\text { all open-ended } \\
\text { mixed }\end{array}$ & \\
\hline & \multirow[t]{3}{*}{$\begin{array}{l}\text { Type of } \\
\text { question }\end{array}$} & $\begin{array}{l}\text { sample, referring to the } \\
\text { population under study in order } \\
\text { to }\end{array}$ & $\begin{array}{l}\text { characterize the population } \\
\text { select the participants who } \\
\text { could provide further } \\
\text { information }\end{array}$ \\
\hline & & \multirow[t]{2}{*}{$\begin{array}{l}\text { aims to obtain information } \\
\text { related to the research topic }\end{array}$} & $\begin{array}{l}\text { targeting the research question } \\
\text { satellite, requiring } \\
\text { complementary information }\end{array}$ \\
\hline & & & $\begin{array}{l}\text { redundant, does not contribute } \\
\text { to the research topic. }\end{array}$ \\
\hline
\end{tabular}

Here we propose an example of the formulation of an hypothesis.

G10VLR Our hypothesis is that more than 50\% of our respondents have donated blood to help others.

Explicit

hypothesis

Below we present examples of questions related to the sample:

G2UAB: Age?

Sex?

Do you currently have a mobile phone?" [The subsequent questions were only addressed to those who had a mobile phone] characterization

selection

We exemplify the characterization of the aim on the basis of the questions linked to the research question, "What food habits or type of diet do the students on our course follow?"

G21SCL: Are you on any kind of diet? Why?

What do you usually eat?

What food is found in your home every day?

$$
\begin{array}{r}
\text { target } \\
\text { satellite } \\
\text { redundant }
\end{array}
$$

Stage 3: Data. Table 5 shows the categories used for the analysis of the third stage - data. The table shows the components defined by Wild and Pfannkuch (1999) to describe the IC data phase, while the categories are those generated by Ubilla et al. (2019) in their study. In the analysis of this stage, we renamed the subcategories attached to the techniques of data collection category established by Ubilla et al. (2019) in order to adapt them to the Chilean data.

Table 5. Categories for Stage 3-Data

\begin{tabular}{lll}
\hline Components & Categories & \\
\hline Data collection & Techniques & $\begin{array}{l}\text { researcher+participant }(+ \text { instrument): The questions are } \\
\text { presented to the participants by the researcher, who } \\
\text { collects the answers. } \\
\text { participant+instrument: the participants record their } \\
\text { answers directly on the instrument }\end{array}$ \\
Data cleaning & $\begin{array}{l}\text { Visual } \\
\text { Non-visual }\end{array}$ \\
\hline
\end{tabular}


Figure 3 presents an example of visual data cleaning, where the G4UAB group identifies the data that does not form part of their study, indicating that three of the 68 people who responded were teachers while their proposal focused on the habits of young people.

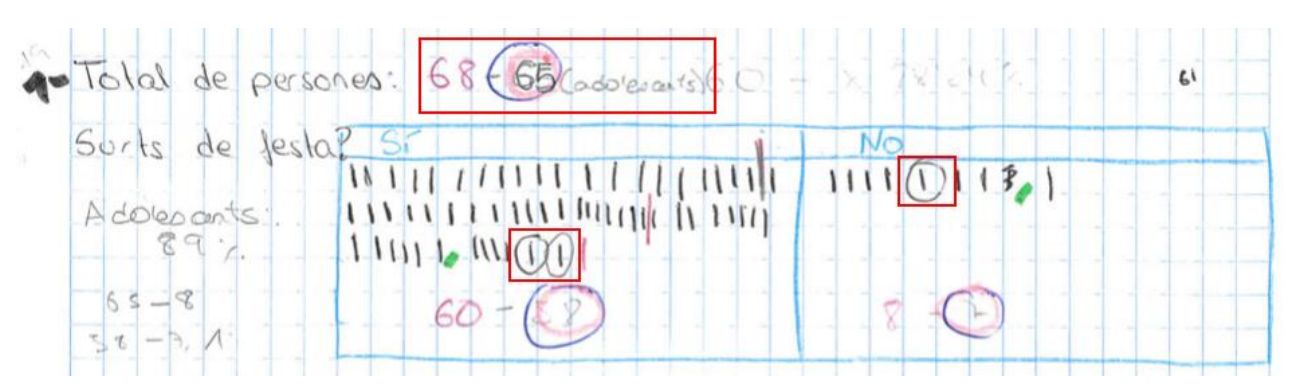

Figure 3. Visual data cleaning (G4UAB)

Stage 4: Analysis. Table 6 presents the categories used in the analysis of the sixth stage - analysis. In the table, the first component of this phase, which is the initial data processing, was defined by Ubilla et al. (2019). The second component, transnumeration, is from Wild and Pfannkuch (1999) and reflects one of the types fundamental to statistical thinking. All the categories in the table come from Ubilla et al. (2019).

Table 6. Categories for Stage 4: Analysis

\begin{tabular}{ll}
\hline Components & Categories \\
\hline Initial processing of data & Frequency records \\
& Category construction \\
Transnumeration & Numerical representation \\
& Graphical representation \\
\hline
\end{tabular}

In Figure 4 we present, by way of an example of the initial data processing, the frequency register for the answers to "how many times have you donated blood?" and the construction of categories for the answers to "why haven't you donated blood?", corresponding to G10VLR. Thus, we see in the lefthand column that a count is made of the number of people who donated blood once, twice, three and five times, and in the right-hand column people are grouped according to their reasons ("I do not meet the requirements"; "I'm afraid"; "I don't want to") and a count is made of how many people there are in each of the categories generated by the collected answers.

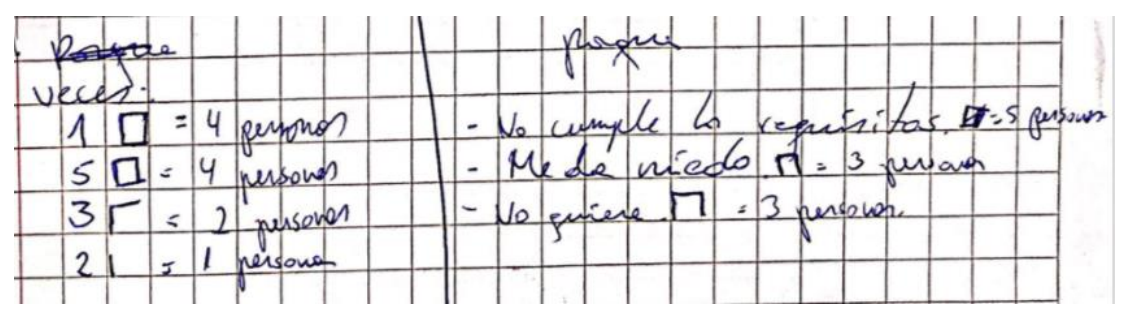

Figure 4. Initial data processing (G10VLR)

In the transnumeration we observe both numerical representations (percentages and centralization measures) and graphical representations (bar charts, pie charts and histograms). Since the representations varied between the centers, we have included these new subcategories in the results. 
Stage 5: Conclusions. The categories used for the analysis of this stage are shown in Table 7. The table shows two of the components - the interpretation of results and the conclusions, defined by Wild and Pfannkuch (1999) to describe the conclusions stage of the IC. The last component and all the categories included in the table were constructed by Ubilla et al (2019).

Table 7. Categories for Stage 5 - Conclusions

\begin{tabular}{|c|c|c|}
\hline Components & Categories & \\
\hline \multirow[t]{2}{*}{ Interpretation of results } & Approach & $\begin{array}{l}\text { partial: referring to their results one by one } \\
\text { relational: establishing relationships between results }\end{array}$ \\
\hline & $\begin{array}{l}\text { Meaning } \\
\text { conveyance }\end{array}$ & $\begin{array}{l}\text { descriptive: only presenting frequencies or } \\
\text { centralization measures, without further interpretation } \\
\text { interpretative: } \quad \text { integrating context information } \\
\text { including new information from } \\
\text { data collection that was not planned } \\
\text { for initially } \\
\text { based on their own beliefs }\end{array}$ \\
\hline Conclusions & \multicolumn{2}{|c|}{$\begin{array}{l}\text { answer the research question } \\
\text { partially answer the research question } \\
\text { do not answer the research question }\end{array}$} \\
\hline $\begin{array}{l}\text { Criticism of their own } \\
\text { work process }\end{array}$ & \multicolumn{2}{|c|}{$\begin{array}{l}\text { Identification of strengths and weaknesses } \\
\text { Suggestions for improvement }\end{array}$} \\
\hline
\end{tabular}

Next, we exemplify the assignment of units of meaning belonging to the interpretation process, indicating the kind of approach taken and the form taken by the attribution of meaning, indicating between \{\} the type it corresponds to:

G4VLR: [... $24.4 \%$ of the population interviewed was male and the remaining $79.6 \%$ was female. [...] In the region most of our classmates come from, $35.7 \%$ of the students live in rural areas and $64.3 \%$ live in urban areas

G8UAB: [...] while almost $75 \%$ of the respondents put on makeup every day, several times a week or on special occasions such as going to a party $[\ldots]$, we also observed that the majority of people who started putting on makeup between the ages of 16 and 18 do so on special occasions $\{$ new information $\}$. We think this circumstance may be related to the admission age at nightlife establishments \{beliefs $\}$.

G18SCL: [...] half of the interviewees had closed their Facebook accounts $(57.1 \%)$, but not necessarily because of what happened with Mark Zuckerberg, because, among these people, only one said it was due to a lack of security.
Partial approach

Descriptive

Partial approach Interpretative Relational approach
Descriptive

\section{RESULTS}

Our analysis revealed differences and similarities in the various phases of the ICs completed by the groups. In the tables that follow, for each stage of the cycle, we present the relative frequency of the categories that contain the data collected at the three centers. In our comments, we focus our attention on those who interest us for the purpose of answering the research question.

When reading the tables, it is important to keep in mind that the sum of the partial percentages is not always 100. The reason for this is that the percentage is established across the total number of working groups at each center. For example, in the rationale category for the UAB groups the percentages add up to less than 100 because only $89 \%$ of the groups proposed a justification for their topic. Contrariwise, when we consider whether they stated a purpose and/or a research question, the sum of the percentages of the UAB groups is greater than 100, since the categories in this case are not exclusive. Thus, all the groups presented a research purpose and, at the same time, $21 \%$ of the groups 
posed a research question, which means that $79 \%$ presented a research purpose without posing a research question.

\section{STAGE 1: PROBLEM}

Table 8. Stage 1-Problem categories at the three centers

\begin{tabular}{|c|c|c|c|c|c|c|}
\hline & & & & \\
\hline & & & & $\begin{array}{l}\text { SCL } \\
(\%)\end{array}$ & $\begin{array}{l}\text { VLR } \\
(\%)\end{array}$ & $\begin{array}{c}\mathrm{UAB} \\
(\%)\end{array}$ \\
\hline \multirow{6}{*}{$\begin{array}{l}\text { Capturing the } \\
\text { dynamics of } \\
\text { the context }\end{array}$} & \multirow{3}{*}{ Rationale } & \multicolumn{2}{|l|}{ relevance } & 50 & 27 & 21 \\
\hline & & \multicolumn{2}{|l|}{ curiosity } & 17 & 33 & 24 \\
\hline & & \multicolumn{2}{|c|}{ unspecified interest } & 33 & 27 & 24 \\
\hline & \multirow[t]{3}{*}{ Research focus } & \multicolumn{2}{|l|}{ explicit } & 67 & 67 & 86 \\
\hline & & setting & studies & 50 & 40 & 12 \\
\hline & & & leisure & 17 & 27 & 74 \\
\hline \multirow{7}{*}{$\begin{array}{l}\text { Problem } \\
\text { definition }\end{array}$} & \multirow{7}{*}{$\begin{array}{l}\text { Research } \\
\text { purpose } \\
\text { and/or question }\end{array}$} & \multirow[t]{2}{*}{ enunciative } & purpose & 0 & 13 & 100 \\
\hline & & & question & 100 & 80 & 21 \\
\hline & & \multirow[t]{2}{*}{ nature } & statistical & 100 & 100 & 100 \\
\hline & & & non-statistical & 0 & 0 & 0 \\
\hline & & \multirow[t]{3}{*}{ type } & summary & 83 & 80 & 68 \\
\hline & & & comparison & 0 & 0 & 21 \\
\hline & & & relationship & 17 & 13 & 12 \\
\hline
\end{tabular}

When analyzing how the students posed their research problem, we observed that the presence of a rationale for the research question varied according to the center, being noteworthy the fact that all the groups at SCL offered a justification, while the percentage of those who did so at VLR was inferior, and even more so at the UAB. Likewise, the setting of the research focus, which shows the main interest of their research, is specified differently, with the fact that leisure topics were of predominant interest at the UAB deserving particular mention, while at SCL and VLR most of the topics were related to the students' studies.

In regard to the distinction, we made between whether they stated the purpose of the research or asked a research question, we observed that while all the SCL groups and a large part of the VLR groups posed research questions, the majority of the groups at UAB only stated the research purpose. The research purposes and questions were of a statistical nature in all cases since the way the activity was planned required this. Moreover, in most cases they were summary questions or purposes, in the sense that they asked for a description of the data from a single data set. At all three centers, questions or purposes seeking relationships between paired variables were rare, while few UAB groups presented questions that required comparison between subsets of data given a common variable.

\section{STAGE 2: PLAN}

Table 9. Stage 2 -Plan categories at the three centers

\begin{tabular}{|c|c|c|c|c|c|c|}
\hline \multirow{4}{*}{$\begin{array}{l}\text { Hypothesis } \\
\text { formulation } \\
\text { Data } \\
\text { collection tool }\end{array}$} & & & & SCL (\%) & VLR (\%) & $\mathrm{UAB}(\%)$ \\
\hline & \multicolumn{3}{|c|}{ Hypothesis to be tested made explicit } & 33 & 20 & 18 \\
\hline & \multirow[t]{3}{*}{ Format } & \multicolumn{2}{|c|}{ closed-ended } & 0 & 40 & 70 \\
\hline & & \multicolumn{2}{|c|}{ open-ended } & 17 & 7 & 6 \\
\hline & & \multicolumn{2}{|l|}{ mixed } & 83 & 53 & 24 \\
\hline & \multirow{5}{*}{$\begin{array}{l}\text { Type of } \\
\text { questions }\end{array}$} & \multirow[t]{2}{*}{ sample } & characterization & 50 & 13 & 41 \\
\hline & & & selection & 0 & 13 & 38 \\
\hline & & \multirow[t]{3}{*}{ aim } & target & 100 & 100 & 100 \\
\hline & & & satellite & 67 & 53 & 12 \\
\hline & & & redundant & 67 & 67 & 47 \\
\hline
\end{tabular}


In relation to the students planning of data collection, we observed that few groups explicitly formulated hypotheses; in the best case, one third of those at SCL. In general, they tended to approach the construction of the data collection tool without developing any prior hypothesis about the results that might be obtained. Regarding the data collection tools they constructed, we observed that those that only proposed open-ended questions were scarce at the three centers, while those of a mixed character dominated at SCL and closed-ended questions prevailed at the UAB. All the groups posed questions intended to directly answer the research question, and the presence of redundant questionsquestions that did not contribute to the research topic - was notable at the three centers. Even though more than half of the groups at SCL and VLR posed satellite questions - those that ask for additional information - this type of question was scarce at the UAB.

\section{STAGE 3: DATA}

Table 10. Stage 3 -Data categories at the three centers

\begin{tabular}{|c|c|c|c|c|c|}
\hline & & & \\
\hline & & & $\operatorname{SCL}(\%)$ & $\operatorname{VLR}(\%)$ & $\mathrm{UAB}(\%)$ \\
\hline \multirow[t]{2}{*}{ Data collection } & Techniques & $\begin{array}{l}\text { researcher }+ \text { participant } \\
(+ \text { instrument })\end{array}$ & 33 & 40 & 74 \\
\hline & & participant+instrument & 67 & 60 & 26 \\
\hline \multirow[t]{2}{*}{ Data cleaning } & Visual & & 0 & 0 & 15 \\
\hline & Non-visual & & 0 & 0 & 0 \\
\hline
\end{tabular}

On studying how they collected their data we observed that, while the predominant data collection technique at SCL and VLR consisted of asking participants to write down their answers directly in the questionnaire, at the UAB an interviewer mediated between the participants and the instrument in the majority of cases.

\section{STAGE 4: ANALYSIS}

Table 11. Stage 4 - Analysis categories at the three centers

\begin{tabular}{|c|c|c|c|c|c|}
\hline & & & \\
\hline & & & SCL $(\%)$ & $\operatorname{VLR}(\%)$ & $\mathrm{UAB}(\%)$ \\
\hline \multirow{3}{*}{$\begin{array}{l}\text { Initial processing } \\
\text { of data }\end{array}$} & \multicolumn{2}{|c|}{ Frequency records } & 67 & 73 & 91 \\
\hline & \multicolumn{2}{|c|}{ Category construction } & 17 & 0 & 0 \\
\hline & \multicolumn{2}{|c|}{ Frequency records + category construction } & 0 & 13 & 9 \\
\hline \multirow[t]{6}{*}{ Transnumeration } & \multirow{2}{*}{$\begin{array}{l}\text { Numerical } \\
\text { representation }\end{array}$} & percentages & 50 & 73 & 76 \\
\hline & & $\begin{array}{l}\text { centralization } \\
\text { measures }\end{array}$ & 0 & 0 & 26 \\
\hline & \multirow{3}{*}{$\begin{array}{l}\text { Graphical } \\
\text { representation }\end{array}$} & bar chart & 33 & 53 & 59 \\
\hline & & pie chart & 50 & 53 & 32 \\
\hline & & histogram & 0 & 6 & 9 \\
\hline & \multicolumn{2}{|c|}{ Graphical + numerical } & 17 & 53 & 56 \\
\hline
\end{tabular}

As far as how they analyzed their data is concerned, we observed that most groups recorded absolute frequencies in their initial data processing. However, at SCL less than a fifth of the groups only constructed categories on analyzing their data, while a few groups at VLR and the UAB combined category construction and frequency registration. As for transnumeration, we observed that percentages were used at all three centers. Only at the UAB were centralization measures used, essentially the mode was used to refer to the idea of "majority". The three centers displayed similarities in their use of graphical representations, with many bar and pie charts and few histograms. Although in the minority, those who used Google Forms ${ }^{\odot}$ to collect the data presented their results using the graphics offered by that program. 


\section{STAGE 5: CONCLUSIONS}

Table 12. Stage 5 categories at the three centers

\begin{tabular}{|c|c|c|c|c|c|c|}
\hline & & & & \\
\hline & & & & $\operatorname{SCL}(\%)$ & $\operatorname{VLR}(\%)$ & $\mathrm{UAB}(\%)$ \\
\hline \multirow{6}{*}{$\begin{array}{l}\text { Interpretation of } \\
\text { results }\end{array}$} & \multirow{2}{*}{ Approach } & \multirow{2}{*}{\multicolumn{2}{|c|}{$\begin{array}{l}\text { partial } \\
\text { relational }\end{array}$}} & 33 & 67 & 59 \\
\hline & & & & 67 & 33 & 41 \\
\hline & \multirow{4}{*}{$\begin{array}{l}\text { Meaning } \\
\text { conveyance }\end{array}$} & \multicolumn{2}{|l|}{ descriptive } & 67 & 80 & 41 \\
\hline & & interpretative & $\begin{array}{l}\text { context } \\
\text { information }\end{array}$ & 0 & 13 & 41 \\
\hline & & & new information & 17 & 7 & 15 \\
\hline & & & beliefs & 33 & 13 & 35 \\
\hline \multirow[t]{3}{*}{ Conclusions } & \multicolumn{3}{|c|}{ answer the research question } & 83 & 67 & 71 \\
\hline & \multicolumn{3}{|c|}{ partially answer the research question } & 0 & 20 & 6 \\
\hline & \multicolumn{3}{|c|}{ do not answer the research question } & 17 & 13 & 24 \\
\hline \multirow{2}{*}{$\begin{array}{l}\text { Criticism of their } \\
\text { own work process }\end{array}$} & \multirow{2}{*}{\multicolumn{3}{|c|}{$\begin{array}{l}\text { strengths and weaknesses } \\
\text { imnrovement }\end{array}$}} & 20 & 87 & 82 \\
\hline & & & improvement & 0 & 0 & 38 \\
\hline
\end{tabular}

On studying how they expressed the conclusions to their research, we observed that two thirds of the SCL groups took a relational approach, that is, they presented their conclusions as a relationship between different partial results. However, at VLR the conclusions of the majority were presented as partial approximations to the interpretation of results, their conclusions being a concatenation of answers to the different questions in the data collection instrument, without relating the results to each other. At the UAB the interpretation of the results in the written conclusions was distributed between the two types of approach, with greater weight on the partial approaches. Most of the groups at SCL and VLR presented descriptive conclusions, with a much higher number at VLR. At the UAB less than half the groups generated descriptive conclusions. When the conclusions had an interpretive character, the groups incorporated information from the research context, new information obtained during the data collection process and their own beliefs. It is especially remarkable that about one third of the groups at SCL and the UAB incorporated their own beliefs in the drafting of the conclusions. For the most part, the groups gave an answer to the research question or the purpose that initiated the research cycle. The VLR and UAB groups reflected on their own process, something much less frequent at SCL. The only proposals for improvement came from the UAB.

\section{DISCUSSION AND CONCLUSIONS}

Numerous studies suggest that the backbone of statistics teaching should be the statistical investigative cycle, both in the English-speaking world (Bright \& Friel, 1998; Franklin et al., 2007; Holmes, 1980; Watson et al., 2018) and the Spanish one (Batanero \& Díaz, 2011). Regardless of the stages they specify and how they label them, these studies agree that the teaching of statistics should focus more on its usefulness for solving problems than on the mastery of decontextualized concepts and procedures. From this standpoint the teacher's role is to accompany the students in the development of statistical investigations. Therefore, teachers must have the knowledge and tools to do so (Batanero \& Borovcnik, 2016; Burgess, 2008).

The guidelines for the implementation of the compulsory education curriculum in Chile (MINEDUC, 2012, 2015, 2019) and the curriculum currently in force in Catalonia (Statutory Orders $119 / 2015$ and 187/2015) reflect this new vision. However, the students whom we are training to be teachers may well have learned statistics as the sum of arithmetical procedures and concepts with little meaning for them. The onus is on foundational training programs to help them link what they learned with what they should teach. This prompted us to explore how future teachers develop a statistical investigation in two similar contexts (all Spanish speakers, with comparable curricular roots and training schemes), but also different (secondary education structures that resulted in distinct previous trajectories). To this end, we invited pre-service teachers to take part in an activity based on the 
investigative cycle (Wild \& Pfannkuch, 1999), which we used as a reference. We studied how they specified the different stages, not so much to evaluate their knowledge but to identify differences and similarities that might help us to guide their training.

The use in our analysis of the categories proposed by Ubilla et al. (2019) provided new elements for a detailed understanding of the stages and components of the investigative cycle. In addition, by working in empirical contexts other than those for which the categories were defined, we were able to expand and validate the proposal in order to characterize the investigative cycle. In this way, thanks to the analysis of the groups' reports when developing an investigative cycle, we were able to identify what concepts and procedures they brought into play, as well as the richness and density of the network of connections they established.

The differences observed in the reports submitted by the groups at the three centers suggests that program admission criteria, together with the intensity and focus of the training received - both during compulsory secondary school and on the teacher training program-influences the richness and robustness of the groups' reports. In addition, the similarities between the centers suggest aspects that should be included in training. Thus, we see that in general the students did not formulate hypotheses and the research questions tended to be of the summary type. For the most part, the groups' data collection tools directly contained the research question and numerous redundant or satellite questions. Watson et al. (2018) mention the limited research on how students collect and organize data. Our research goes some way to address that gap. It suggests there are links among the format of the instrument questions, the data collection techniques, and the analysis. Closed questions may result in a collection technique that requires an interviewer, who mediates between the instrument and participants, asking the questions and processing the answers through frequency registration. The data collection technique applied to open questions may not require the presence of the researcher and the data could be processed by establishing categories.

In the case of transnumeration, we observed the coexistence of numerical and graphical representations with similar graphics but differences in the numerical representations. The use of the concept of mode was only identified at one center. Again, this may be linked to the questions in the data collection instrument and may demonstrate poor connections made among concepts and their use in context (Batanero \& Díaz, 2011). The conclusions were essentially descriptive and formulated as an aggregate of results of the different questions in the instrument, without the results being related to each other. The conclusions often contained arguments based on both results and beliefs, essentially in the SCL and UAB groups, but not at VLR. This difference in the presentation of conclusions may have more to do with the similarities in the curricula followed by the participants in Chile and Spain than with other differences. The conclusions presented by the VLR groups were essentially descriptive, so that by not interpreting the results further they did not need to resort to their beliefs. However, a significant number of groups at the UAB and even more at SCL, came to their conclusions by interpreting the results more extensively, thereby drawing on contextual information, new information, and their beliefs. This is probably because learning to draw conclusions from results was not part of the compulsory curriculum they had followed.

Despite the intensity with which the intentional curriculum in force during the compulsory education of the participants in the study specified content and objectives, we observed that the said content and objectives were not part of the learned curriculum. Therefore, when interpreting our results, it was more important to focus on teaching methods than on the curriculum. Therefore, we can conclude that there is a need to generate learning instances that permit the insertion of statistics in context so that future teachers can link what they have learned and what they should teach. We suggest the investigative cycle as an instrument to do so. The investigative cycle enables students to ask questions of a statistical nature; select the sample and determine its size, formulate research questions and hypotheses (Arnold, 2013); build data collection instruments; reflect on how the instrument questions condition data collection techniques, the type of data, the way of analyzing it and the type of results obtained; provide centralization and dispersion measures with meaning in context; write conclusions based on evidence, relating partial results to the research question and context; and critically use information and communication technologies. 


\section{ACKNOWLEDGEMENTS}

We would like to thank the students who participated in the study and the teachers who allowed us to use their classes to collect the research data.

This study was carried out under the umbrella of the project "Estudio de los requisitos de acceso a los grados de Maestro de Educación Primaria desde la perspectiva del conocimiento matemático" (Study of the Admission Requirements for Primary Education Teacher Degrees from the Perspective of Mathematical Knowledge), funded by the Department of Research, Development and Innovation of the Ministry of Science, Innovation and Universities of Spain, with reference EDU2017-8247-R.

The first author carries out her research with the support of an International Postgraduate Scholarship funded by the National Commission of Scientific and Technological Research of Chile, whose reference is CONICYT PFCHA/DOCTORADO BECAS CHILE/2018 - 72190313.

This work has been developed within the framework of the $\mathrm{PhD}$ program in Education at Autonomous University of Barcelona.

\section{REFERENCES}

Arnold, P. M. (2013). Statistical investigative questions. An enquiry into posing and answering investigative questions from existing data. [Doctoral Dissertation, University of Auckland]

Arnold, P., \& Pfannkuch, M. (2019). Posing comparative statistical investigative questions. In G. Burrill \& D. Ben-Zvi (Eds.), Topics and trends in current statistics education research (pp. 173-195). Springer.

Arteaga, P. (2011). Evaluación de conocimientos sobre gráficos estadísticos y conocimientos didácticos de futuros profesores. [Evaluation of knowledge on statistical graphs and didactic knowledge of future teachers] [Doctoral dissertation, University of Granada]

Batanero, C., \& Borovcnik, M. (2016). Statistics and probability in high school. Sense Publishers.

Batanero, C., \& Díaz, C. (Eds.). (2011). Estadística con proyectos. [Statistics with projects] Departamento de Didáctica de la Matemática.

Begg, A. (1997). Some emerging influences underpinning assessment in statistics. In I. Gal \& J. Garfield (Eds.), The assessment challenge in statistics education (pp. 17-25). IOS Press.

Ben-Zvi, D., Makar, K., \& Garfield, J. (Eds.). (2018). International handbook of research in statistics education. Springer.

Bright, G. W., \& Friel, S. N. (1998). Graphical representations: Helping students interpret data. In S. P. Lajoie (Ed.), Reflections on statistics: Learning, teaching, and assessment in grades $K^{-1} 12$ (pp. 6388). Lawrence Erlbaum.

Burgess, T. (2008). Teacher knowledge for teaching statistics through investigations. Joint ICMI/IASE Study: Teaching Statistics in School Mathematics. Challenges for Teaching and Teacher Education. Proceedings of the ICMI Study 18.

Cohen, L., Manion, L., \& Morrison, K. (2000). Research methods in education (5th ed.). Routledge Falmer.

Decret 119/2015, de 23 de juny, del Departament d'Educació de la Generalitat de Catalunya, pel qual s'estableix l'ordenació dels ensenyaments de l'educació primària. [Statutory Order 119/2015, passed on 23 June, Department of Education of the Generalitat Government of Catalonia, which regulates primary education] http://xtec.gencat.cat/ca/curriculum/primaria/normativa/

Decret 143/2007, de 26 de juny, del Departament d'Educació de la Generalitat de Catalunya, pel qual s'estableix l'ordenació dels ensenyaments de l'educació secundaria obligatòria. [Statutory Order 143/2007, passed on 26 June, Department of Education by the Generalitat Government of Catalonia, which regulates compulsory secondary education] http://cido.diba.cat/legislacio/936598/decret-1432007-de-26-de-juny-pel-qual-sestableixlordenacio-dels-ensenyaments-de-leducacio-secundaria-obligatoria]

Decret 187/2015, de 25 d'agost, del Departament d'Educació de la Generalitat de Catalunya, pel qual s'estableix l'ordenació dels ensenyaments de l'educació secundaria obligatòria. [Statutory Order 187/2015, passed 25 August, Department of Education of the Generalitat Government of Catalonia, which regulates compulsory secondary education] http://xtec.gencat.cat/ca/curriculum/eso/normativa/ 
Decreto Supremo No. 254 de la República de Chile que modifica decreto supremo no 220, de 1998, del Ministerio de Educación que establece los objetivos fundamentales y contenidos mínimos obligatorios de la educación media y fija normas generales para su aplicación. [Statutory Order No. 254 of the Republic of Chile amending Statutory Order No. 220 of 1998 of the Ministry of Education, which establishes the fundamental goals and minimum compulsory content of secondary education and lays down general standards for their application] https://www.leychile.cl/Navegar?idNorma=1005222

Franklin, C., Kader, G., Mewborn, D., Moreno, J., Peck, R., Perry, M., et al. (2007). Guidelines for assessment and instruction in statistics education (GAISE) report: A preK-12 curriculum framework. American Statistical Association.

Gal, I. (2002). Adults' statistical literacy: Meanings, components, responsibilities. International Statistical Review, 70(1), 1-25.

Garfield, J. (2002). The challenge of developing statistical reasoning. Journal of Statistics Education, 10(3). https://doi.org/10.1080/10691898.2002.11910676

Holmes, P. (1980). Teaching statistics 11 -16. Schools Council Publications and W. Foulsham.

Makar, K., \& Fielding-Wells, J. (2011). Teaching teachers to teach statistical investigations. In C. Batanero, G. Burrill, \& C. Reading (Eds.), Teaching statistics in school mathematics: Challenges for teaching and teacher education (pp. 347-358). Springer.

Makar, K., \& Rubin, A. (2018). Learning about statistical inference. In D. Ben-Zvi, K. Makar \& J. Garfield (Eds.), International handbook of research in statistics education (pp. 261-294). Springer.

MINEDUC. (2012). Bases curriculares Primero a Sexto Básico. [Curricular bases Grades One through Six Basic Education] Ministerio de Educación. https://www.curriculumnacional.cl/614/articles22394_bases.pdf

MINEDUC. (2015). Bases curriculares $7^{\circ}$ básico a $2^{\circ}$ medio. [Curricular bases Grade Seven Basic Education through Grade two Middle Education] Ministerio de Educación. https://www.curriculumnacional.c1/614/articles-37136_bases.pdf

MINEDUC. (2019). Bases curriculares $3^{\circ}$ y $4^{\circ}$ medio. Plan de Formación General, Plan de Formación Diferenciada Humanístico-Científico. [Curricular Bases Grades Three and Four Middle Education. General Education Plan, Differentiated Humanistic-Scientific Education Plan] Ministerio de Educación. https://www.curriculumnacional.cl/614/articles-91414_bases.pdf

Pfannkuch, M., Arnold, P., \& Wild, C. (2015). What I see is not quite the way it is: Students' emergent reasoning about sampling variability? Educational Studies in Mathematics, 88(3), 343-360.

Pfannkuch, M., \& Horring, J. (2005). Developing statistical thinking in a secondary school: A collaborative curriculum development. In G. Burrill \& M. Camden (Eds.), Curricular development in statistics education: International Association for Statistics Education (pp. 204-218). International Statistics Institute.

Ubilla, F., Gorgorió, N., \& Prat, M. (2019). The investigative cycle: developing a model to interpret the written statistical reports of pre-service primary school teachers. In U. T. Jankvist, M. Van den Heuvel-Panhuizen \& M. Veldhuis (Eds.), Proceedings of the Eleventh Congress of the European Society for Research in Mathematics Education (pp. 1093-1100). Freudenthal Group \& Freudenthal Institute, Utrecht University and ERME.

Vásquez, C., \& Alsina, A. (2017). Aproximación al conocimiento común del contenido para enseñar probabilidad desde el modelo del conocimiento didáctico-matemático. [Approach to the common contentknowledge to teach probability from the didactic-mathematical knowledge model] Educación Matemática, 29(3), 79-108.

Vásquez, C., \& Alsina, A. (2019). Conocimiento especializado del profesorado de educación básica para la enseñanza de la probabilidad. [Specialized content knowledge of basic education teachers for the teaching of probability] Profesorado, Revista de Currículum y Formación del Profesorado, 23(1), 393-419.

Watson, J., Fitzallen, N., Fielding-Wells, J., \& Madden, S. (2018). The practice of statistics. In D. BenZvi, K. Makar, \& J. Garfield (Eds.), International handbook of research in statistics education (pp. 105-137). Springer. 
Wild, C., \& Pfannkuch, M. (1999). Statistical thinking in empirical enquiry. International Statistical Review, 67(3), 223-248.

FRANCISCA M. UBILLA Departament de Didàctica de les Matemàtiques i les Ciències Experimentals Facultat de Ciències de l'Educació Edifici G-5, 142 Plaça del Coneixement 08193 Bellaterra (Cerdanyola del Vallès) Barcelona, Spain 